\title{
Responding to Academic Critiques of Sex Work: Practical Suggestions from a Sex-Positive Perspective
}

\author{
Jeremy N. Thomas, PhD \\ Idaho State University and Center for Positive Sexuality
}

While the prevalence of sex workers and the size and growth of the sex industry is regularly disputed and/or misrepresented (Weitzer, 2007), by all accounts, sex work forms a significant part of the American economy. Whether prostitution, erotic massage, escorting, dancing, modeling, pornography, or providing BDSM and fetish services - sex work and sex workers are available virtually everywhere, and depending on the particular service involved, are utilized by anywhere from a small but substantial portion of the population (e.g., prostitution; Monto \& McRee, 2005) to a large percentage of adults (e.g, pornography; Carroll et al., 2008; Döring, 2009).

Needless to say, many persons find this problematic. Indeed, drawing on religious rhetoric (Thomas, 2013) as well as popular notions of decency (Heins, 2007) and sentimentality (Ericsson, 1980), many Americans are quick to offer moral condemnation of these practices (Sherkat \& Ellison, 1997; Weitzer, 2006). In this article, however, I want to look beyond just popular opinion, and I want to consider how academics have often responded to sex work. In particular, I am interested in why it is that although academics have frequently come to the defense of other popularly-controversial aspects of sexuality - for example, homosexualitywhen it has come to sex work, academics have typically been much more hesitant to counter popular opinion.

To help make sense of this, I present three standard academic critiques of sex work that I suggest have often held academics back from taking a more sex-positive perspective. Although I only present the basic contours of these critiques, I present them with the intent of highlighting how a more sex-positive perspective could respond to these critiques in a helpful and constructive manner. That is, instead of simply dismissing or attempting to undermine these critiques, I ask, how might academics respond to these critiques in ways that could be both practically beneficial as well as broadly applicable? — not just for other academics, but also for clinicians and policy makers, as well as for those who either work in the sex industry or utilize the services that the industry provides. Accordingly, I now present three standard academic critiques of sex work, after which, I offer three corresponding responses.

\section{Three Standard Academic Critiques of Sex Work}

While academic critiques of sex work are wide-ranging and often quite sophisticated (Zatz, 1997), I suggest that in basic form there are really three standard critiques that have subsequently been adapted and integrated in a variety of ways. The first of these is the Marxist critique. This critique derives from Marx's general critique of capitalism (1976) as well as Engels' specific application of this critique to the family structure (2010). At root, this critique can be summed up in Marx's aphorism that "Prostitution is only a particular expression of the universal prostitution 
of the worker..." (1992, p. 350). By this, Marx meant that just as the general workings of capitalism are inherently exploitive (e.g., owners profiting from and mistreating their workers), so too, sex work is inherently exploitive (e.g., pimps and club owners profiting from and mistreating their prostitutes and dancers). One of the interesting corollaries to this is that the Marxist tradition has frequently argued that just like workers in any other industry, the exploitation of sex workers is not constant but rather varies significantly across situations and contexts (Ericsson, 1980; Kesler, 2002). In particular, when sex work takes place in less regulated environments (e.g., child brothels in Thailand), sex workers are subject to greater levels of exploitation, while in more regulated environments (e.g., adult brothels in Nevada), such exploitation is decreased.

The second standard academic critique of sex work is the radical feminist critique. Often identified with the writings of Dworkin (1981) and MacKinnon (1989), the radical feminist critique argues that sex work is not only exploitive because owners profit from and mistreat their workers, but more critically, because owners are overwhelmingly male, and workers are overwhelmingly female. This promotes the idea that sex work is not really about selling sexual services, but actually about selling women themselves (Barry, 1979, 1995). In turn, the radical feminist critique argues that this kind of objectification leads to the further mistreatment of sex workers by both owners and buyers - which ultimately results in the similar mistreatment of women more generally (Dines, 2010). In sum, the radical feminist critique argues that sex work reinforces patriarchy and heteronormativity. Sex work, it is claimed, turns women into sexual objects to be used and mistreated by men.

The third standard academic critique of sex work is the critical theory critique. While this critique is perhaps the least likely to be specifically identified, in many ways, it is the most powerful and enduring of the three standard critiques. Based primarily on the work of Marcuse $(1955,1964)$, the critical theory critique argues that when sex becomes something that is bought and sold, both the buyer and the seller lose a part of themselves in the transaction. The idea here is that in its natural form, sexuality is a creative energy that in order to be fully experienced must be freely given and freely received (Horkheimer \& Adorno, 2002). Hence, when sex enters the marketplace, its creative energy becomes regimented and diminished through the constraints of exchange and consumption (Fleming, 2007). No matter how consensual and pleasurable the experience may be, the critical theory critique argues that the sale of sex fundamentally degrades its creative character, and in turn, both buyers and sellers become alienated from their own sexualities.

\section{Responding Instead of Dismissing}

Many advocates of the above critiques - whether Marxist, radical feminist, or critical theoryargue that sex work of all kinds should be discouraged, resisted, and made illegal or at least difficult and costly to access (e.g., Jeffreys, 2009). Alternatively, some proponents of sex work argue that these critiques are invalid and should simply be dismissed. Instead of either of these options, I suggest taking a more sex-positive perspective. That is, rather than trying to adjudicate evidence and trying to assess the validity of these critiques, I propose giving each of them the benefit of the doubt, and then asking, given that sex work and the sex industry is not likely to be going away any time soon, how we might respond to these critiques in a helpful and constructive 
manner? Accordingly, I now offer three responses that lay out some practical suggestions that could be promoted by academics and then implemented by clinicians and policy makers, as well as by those who either work in the sex industry or utilize the services that the industry provides. Although these responses are not necessarily new and have in large part been articulated elsewhere (e.g., Bell, 1994; Chapkis, 1997; Rubin, 1984), nonetheless, I think it is still helpful to identify and describe some basic sex-positive responses.

First, to the degree that the Marxist critique may have some validity in arguing that sex work is an inherently exploitive labor practice, I suggest that the appropriate response lies in advocating for the kinds of occupational regulations that will reduce this exploitation. In particular, academics should not only call for the decriminalization and legalization of consensual, adult sex work, but they should also call for fair labor practices, for profit sharing, for safe workplaces, and especially for the opportunity for sex workers to be self-employed as desired. Now, obviously, much of the current regulation of sex work is not at all intended to support these goals but actually is intended to limit and discourage sex work. Hence, when it comes to implementing new regulations, it is imperative that policy makers partner with sex workers in developing these regulations, so that these regulations properly serve the interests of sex workers. To be clear, regulation must support and protect sex workers, not further exploit them.

Second, to the degree that the radical feminists critique may have some validity in arguing that sex work reinforces patriarchy and heteronormativity, I suggest that the appropriate response lies in advocating for the diversification and queerification of sex work. With regard to the gender of sex workers, academics should be especially supportive of sex workers who identify as male, trans, or otherwise genderqueer. Likewise, with regard to sexual services, academics should be especially supportive of queer and alternative services such as those provided by gay escorts and lesbian dancers, as well as by professional dominants and submissives, by alternative pornography actors, and by fetish service providers. By means of such diversification and queerification, sex work can move away from reinforcing patriarchy and heteronormativity and actually begin to undermine these hegemonic structures.

Third, to the degree that the critical theory critique may have some validity in arguing that sex work alienates buyers and sellers from their own sexualities, I suggest that the appropriate response lies in advocating for the legitimation and celebration of sex work as a creative occupation that not only provides an important source of income for many persons but can also be personally meaningful and fulfilling. While there are many ways in which this might be understood (e.g., in a therapeutic sense, an entertainment sense, or a self-actualization sense), regardless of the particularities, academics should encourage others to see sex work as a creative enterprise, as acceptable and important as any other line of work. Alongside this academic encouragement, clinicians can also play a valuable role in supporting these kinds of ideas. Finally, sex workers, as well as those who utilize their services, can both be intentional in respecting and validating - and thus reifying - the creative dimensions of their mutual interactions.

\section{Conclusion}


In many environments, the conditions of sex work are obviously less than ideal. Indeed, claims that sex work is exploitive, patriarchal, heteronormative, and alienating are not without merit. Yet, at the same time, such claims do not accurately describe the situations of many sex workers. Rather, as research has increasingly found (Weitzer, 2009), the conditions of sex work, as well as the personal assessments of sex workers, actually vary significantly. This suggests, then, that even if one has overarching concerns about sex work, regardless of such concerns, it should be relatively straightforward to agree to advocate for practical ways to improve the environments and conditions under which sex work takes place. However, beyond just this, a sex-positive perspective must go further and must reject the latent moralizing and fundamental uneasiness about sexuality that clearly pervades academic critiques of sex work and that undoubtedly contributes to the very problems that these critiques identify. Instead, academics - along with clinicians and policy makers, as well as those who either work in the sex industry or utilize the services that the industry provides - should together advocate not only for the decriminalization and legalization of consensual, adult sex work, but also for the legitimation and celebration of such work as both a necessary and desirable part of the human experience.

\section{References}

Barry, K. (1979). Female sexual slavery. New York: New York University Press.

Barry, K. (1995). The prostitution of sexuality. New York: New York University Press.

Bell, S. (1994). Reading, writing, and rewriting the prostitute body. Bloomington, IN: Indiana University Press.

Carroll, J. S., Padilla-Walker, L. M., Nelson, L. J., Olson, C. D., Barry, C. M., \& Madsen, S. D. (2008). Generation XXX: Pornography acceptance and use among emerging adults. Journal of Adolescent Research, 23(1), 630.

Chapkis, W. (1997). Live sex acts: Women performing erotic labor. New York: Routledge.

Dines, G. (2010). Pornland: How porn has hijacked our sexuality. Boston, MA: Beacon Press.

Döring, N. M. (2009). The Internet's impact on sexuality: A critical review of 15 years of research. Computers in Human Behavior, 25(5), 1089-1101.

Dworkin, A. (1981). Pornography: Men possessing women. New York: Perigee Books.

Engels, F. (2010). The origin of the family, private property and the state. New York: Penguin Classics.

Ericsson, L. O. (1980). Charges against prostitution: An attempt at a philosophical assessment. Ethics, 90(3), 335-366.

Fleming, P. (2007). Sexuality, power and resistance in the workplace. Organization Studies, 28(2), 239-256.
Heins, M. (2007). Not in front of the children: 'Indecency,' censorship, and the innocence of youth (2nd. ed.). New Brunswick, NJ: Rutgers University Press.

Horkheimer, M., \& Adorno, T. W. (2002). Dialectic of enlightenment: Philosophical fragments. Redwood City, CA: Stanford University Press.

Jeffreys, S. (2009). The idea of prostitution (2nd. ed.). North Melbourne, Australia: Spinifex Press.

Kesler, K. (2002). Is a feminist stance in support of prostitution possible? An exploration of current trends. Sexualities, 5(2), 219-235.

MacKinnon, C. A. (1989). Toward a feminist theory of the state. Cambridge, MA: Harvard University Press.

Marcuse, H. (1955). Eros and civilization: A philosophical inquiry into Freud. Boston, MA: Beacon Press.

Marcuse, H. (1964). One-dimensional man: Studies in the ideology of advanced industrial society. Boston, MA: Beacon Press.

Marx, K. (1976). Capital: A critique of political economy (Vol. 1). New York: Penguin Books.

Marx, K. (1992). Economic and philosophic manuscripts (1844) Karl Marx: Early writings (pp. 279-400). New York: Penguin Books.

Monto, M. A., \& McRee, N. (2005). A comparison of the male customers of female street prostitutes with national samples of men. 
Prior and Williams_https://doi.org/10.51681/1.114

International Journal of Offender Therapy and Comparative Criminology, 49(5), 505529.

Rubin, G. (1984). Thinking sex: Notes for a radical theory of the politics of sexuality. In C. S. Vance (Ed.), Pleasure and danger:

Exploring female sexuality (pp. 267-319). Boston, MA: Routledge.

Sherkat, D. E., \& Ellison, C. G. (1997). The cognitive structure of a moral crusade: Conservative Protestantism and opposition to pornography. Social Forces, 75(3), 957980.

Thomas, J. N. (2013). Outsourcing moral authority: The internal secularization of evangelicals' anti-pornography narratives. Journal for the Scientific Study of Religion, 52(3), 457-475.

Weitzer, R. (2006). Moral crusade against prostitution. Society, 43(3), 33-38.

Weitzer, R. (2007). The social construction of sex trafficking: Ideology and institutionalization of a moral crusade. Politics and Society, 35(3), 447-475.

Weitzer, R. (2009). Sociology of sex work. Annual Review of Sociology, 35, 213-234.

Zatz, N. D. (1997). Sex work/sex act: Law, labor, and desire in constructions of prostitution. Signs: Journal of Women in Culture and Society, 22(2), 277-308. 